\title{
A Fresh Look at Recently Published Anatolian Hieroglyphic Seals
}

\author{
Massimo Poetto* \\ * - University of Bari, emeritus. Email: poemax@libero.it
}

Abstract: Reexamination of Anatolian seals bearing legends in Hieroglyphic Luwian with revision and improvement of the readings presented in former editions.

Keywords: Anatolian glyptics, Hieroglyphic Luwian, Hittite, onomastics

Cite as Poetto, M. 2020: A Fresh Look at Recently Published Anatolian Hieroglyphic Seals. Hungarian Assyriological Review 1: 105-120 https://doi.org/10.52093/hara-202002-00008-000

(c) (i) $($ This is an open access article distributed under the terms of the Creative Commons Attribution License, which permits unrestricted use, distribution, and reproduction in any medium, provided the original author and source are credited.

1) This stamp seal (Fig. 1.1) appears in the presentation by Ishida of the cuneiform tablets from the Middle Euphrates Region belonging to the Hirayama Collection, seal no. 057, tablet no. $13 .{ }^{1}$ The reading of the name of the personage ${ }^{2}$ as "I+ra/ri-na / Irna" 3 has to be emended to $\mathrm{Mar}^{+r}-n$ (M 128+r-36 / L 462+389.2-354). For a further recent example of the sign M 128 +r/ L 462+389.2 see a gorgeous silver signet-ring of the end of the Middle Hittite period from Ortaköy-Sapinuwa. ${ }^{5}$

The small element 厄ु behind the figure's head is hard to identify, but it seems not to be a part of the man's name (thus a second title rather than a weird space filler?).

2) In 2017 B. Dinçol proposed the interpretation of the legend on the central field (Fig. 1.2a-b) of a bulla, ${ }^{6}$ incomplete on the margin, unearthed at Alaca Höyük in 2012 (Fig. 1.3), ${ }^{7}$ another fragment of which (from the 1939 excavations) had previously been published by Güterbock. ${ }^{8}$

The author's exegesis as "L.186 - L.247 - L.329 - L.90 ( $L u$-DOMUS-kwi/a-ti)", which was read as "Luparnakwati or Luparnakwiti" (an anthroponym that "has not been encountered hitherto"), ${ }^{9}$

1 Ishida (2017-2018, 54, see also 20 Fig. 3). Actually to be found already in Ishida (1991, 17; to be rotated $90^{\circ}$ counterclockwise).

2 A 'son of the king' (LUGAL.DUMU / REX.FILUS [M 276 / L 46]). On the value of this expression see Poetto 1992, 435 with references and, for some further examples, Ch. Lebrun 2014, 161 and Yamada 2019, 113 ad nos. "(10-11)".

3 By Mitsuo Nakamura (so Ishida 2017-2018, 30 ad “Acknowledgements”), retained by Yamada $(2019,112)$.

4 For the decryption of the initial glyph cf. Melchert 1988, 36-38, substantiated by Hawkins $(2006,27$ §21).

5 Süel - Weeden 2019.

6 Dinçol 2017, 227-228, Figs. 2a-c.

7 Çınaroğlu et al. 2014, 13, Fig. 1 (overturned).

8 Güterbock 1951, 196 ad “B.1.1. Al.d. 12”, pl. LXXVI, figs. 1a, 1b (upside-down).

9 Dinçol 2017, 227. 
must be partly rectified: instead of "Lu-" (M 316 / L 186 "Étoile à quatre branches"10/445) the document shows LUGAL.DUMU.MUNUS (M 276a*/ L 46.2 "REX.FILIA") 'princess'; top right stands M 219+365 / L 248 (i.e. "247 DOMUS+381 MINUS = DELERE”), with the value $M A R(A){ }^{-11}$ (see my modified drawing in Fig. 1.4), followed (as rightly given in the edition) by M 160 / L $329 \mathrm{kwa} / \mathrm{i}-\mathrm{M} 82$ / L $90 \mathrm{ti}$. The shadings on the edge of the glyphs are the smudges of the impression left on the fresh clay.

This new gyneconym MAR(A)kwa/iti' ${ }^{12}$ aptly matches the masculine Marak(k)ui (Ma(-a)-ra(-ak)$\mathrm{ku}-\mathrm{i}){ }^{13}$ with a -ti-enlargement ${ }^{14}$ as in, e.g., ${ }^{\mathrm{f}} \mathrm{Muwat}(t) i \mathrm{vs} .{ }^{\mathrm{m}} \mathrm{Muwa} .{ }^{15}$

3) This interesting cylinder seal discovered at Elbistan-Karahöyük during the 2016 excavations ${ }^{16}$ was philologically presented by Alparslan and Uysal in 2018 (reproduced here, Fig. 2.1-2). ${ }^{17}$

The legend on the left register was read "L.115 (LEPUS/tapa) - L.209 (i(a)) -*515" (= M 121-171$\left.300 \mathrm{~b}^{*}\right){ }^{18}$ However, the big-eared protome in the beginning of the column can hardly represent a hare head; rather, it depicts a wide- and roundish-eared donkey muzzle, i.e. ta (dextroverse; cf. M 92[a] / L 100), as it can also be perceived from the jaw shape, typical of the equids. Together with the sign underneath (M 171[.1] / L 209 [1st var.]) the interpretation of this andronym (given the identifier $\Delta$. IL 'vir') is thus Ta-a/i(a)/Taya/, equivalent to Tá-a/i(a) ${ }^{19}$ on a number of new bilingual clay sealings (responding to cun. Ta-a'-e) from Karkemish.

Also for the female name Ki-ki-á (M 214-214-17 / L 446-446-19.2 [varr.], characterized by the specular combination for 'woman' [ $\triangle$.MUNUS] on either side) in the first column of the following register, a direct correlation can be established. One side of a seal of the Ashmolean Museum actually bears ${ }^{20}$ the gyneconym $\mathrm{Ki}-\mathrm{ki}-\mathrm{a} / \mathrm{i}(\mathrm{a}){ }^{21}$ if my suggestion ${ }^{22}$ that final -á corresponds to -a/i(a) in various occurrences on glyptics is sound, then this link turns out to be impeccable. In that case, these names could join the series of "élargissement[s] en - $a$ "23 (as well as -ya, cf., e.g., also Hitt. Tatti vs. Tattiya $\left.{ }^{24}\right)$, to which Hier. Tù-Wa/wi-à (m. ${ }^{25}$ (vs. Tù-Wa/wi-á: see below) might belong too. ${ }^{26}$

10 With the author's reading of this sign perhaps influenced by Güterbock (1951, 196; description 195-196 $s u b$ "V. Empreintes - B.1.1”): “On y voit au milieu quelques hiéroglyphes parmi lesquelles on voit un carré et une étoile à quatre rayons [italics mine]")?

11 Cf. Melchert 1988, 34-36, 38. The appended vertical "stroke” (missing in B. Dinçol’s drawing) is still discernible on the photographs.

12 Still unregistered in Zehnder (2010).

13 Laroche 1966, 113 no. 755; 1981, 25; Rüster - Wilhelm 2012, 266b; add m Ma-ra-ku-in (acc.; a 'charioteer') in $H K M$ no. 44 (Mşt. 75/86) vo. 3' (Alp 1991, 196-197, with 78).

14 For which see Laroche 1966, 332 ad 8; Zehnder 2010, 96 no. 27.

15 Laroche 1966, 124 no. 838 and Zehnder 2010, 224-225, with literature; Laroche 1966, 122 no. 832; 1981, 27.

16 Uysal - Çifçi 2018, 577, Fig. 11 (photograph of the object).

17 Alparslan - Uysal 2018, 237a, Figs. 3 and 4 (photograph and drawing of the piece, respectively).

18 Alparslan - Uysal 2018, 236b.

19 A 'son of the king' (see n. 2 above), professionally a 'charioteer of (the goddess) Kubaba': see Peker (2017, 178-179). - On the distribution and use of the Hieroglyphic signs ta and tá (M 65 / L 29), Vertegaal's (2019) recent analysis does not appear cogent.

20 As already referred in Alparslan - Uysal 2018, 236b n. 1.

21 Cf., e.g., Kennedy 1958, 70 no. 15 [B], Pl. II; Laroche 1966, 92 no. 569; cf. also Zehnder 2010, 188.

22 Poetto 2010, 272 §§3-4.

23 Treated in Laroche (1966, 245-246), cf. also Zehnder 2010, 70 §165.

24 Laroche 1966, 181 nos. 1304-1305.

25 Herbordt 2005, nos. 470-471, Pls. 37 and 36 with Hawkins' (2005, 276b) observations.

26 Differently Simon (2013, 3-4): -á marks the end of the word and does not have a real phonetic value; therefore Ki-ki-á and Ki-ki-i(a) are not identical, but Ki-ki-i(a) is a derivative of $K i$-ki-á(/Kiki/), exactly as in the quoted pattern Tatti: Tattiya. Similarly, Tù-wa/wi-á may match Duwaia, though the latter can be 
Finally, the last row of signs in this register, again with the personal name ending in -á and the pairing $\Delta$.IL for 'vir' here at the bottom. The interpretation of the initial pictogram ("in dieser Form etwas problematisch" ${ }^{27}$ ) as " $z u$ " (M 298.2 / L 285) is far-fetched; the discarded alternative "Ein L.88 (tu) [/ M 81 tù, dextroverse] käme [...] ebenfalls in Frage, der Name würde dann Tuwa gelesen werden müssen" ${ }^{28}$ appears, instead, the right option. ${ }^{29}$ The PN Tù-Wa/wi-á matches thus Cun. Duwaia ( ${ }^{\mathrm{m}} \mathrm{Du}$-wa-a-i[a, KBo 44.1 ro. 4').

4) This seal impression, found during the 1955 excavations in the Palais royal d'Ugarit, was first published by Masson ${ }^{30}$ and recently republished by André-Salvini and Salvini ${ }^{31}$ (Fig. 3.1-2).

Masson interpreted the vertical script as "Hu-li-à-na-nî" - partly shared by Mora ("Hu-li-à?-tà/ (ní?)”) $)^{32}$ and Zehnder (“(m) Hu-li-a-na-ni?"), ${ }^{33}$ but in toto by Laroche and Beyer ${ }^{34}$-, while AndréSalvini - Salvini modified it into " $w a / w i$ ? - pi - a-na- ni", with the erroneous insertion: "Le même signe ni (HH 411), inversé, est répété à l'intérieur du signe précédent (na)”.

It should be emphasized, however, that the element on top is not a hieroglyph, but the representation of a bird with wings aligned along the body and head turned rightwards (my drawing, Fig. 3.3), an iconographic component comparable with the one portrayed in this same configuration curiously upside-down and head facing left - on a Meskene-Emar tablet, on the right of the god's turned head (here Fig. 3.4a-b). ${ }^{35}$

Below this image is the first sign of the name, two antithetic, superimposed feet (M 84/ L 96) with the value Tarpa-, which return, e.g., at the beginning of an andronym (a 'son of the king' [see n. 2]) on a stele kept in Afyon Museum (1l. 2, $\left.5^{36}\right)$; in later Hieroglyphic texts the name is written Tarpa- (KULULU lead strip 3a, cols. 16-1737 / ASSUR letter a l. 2 \$6 ${ }^{38}$ ). In Cun. Hittite it is likewise not widespread. ${ }^{39}$

The completion of the personal name is made by the glyphs -n-na/ni ( $\mathrm{n}$ [M 36[b] / L 35] sinistroverse, na/ni [M 388 / L 411] dextroverse, correctly singled out in the previous editions); thus, in full, Tarpanani, with -nani = 'brother'. On the left stands the ordinary designation $\Delta$. .IL 'vir'.

a derivative of /Tuwa/ too.

27 Alparslan - Uysal 2018, 237a.

28 Alparslan - Uysal 2018, 237 n. 3.

29 Such untypical shape should be added to the manifold variants of the glyph presented in Herbordt (2005, 403), with Hawkins' (2005, 432b) description.

30 Masson 1975, 227 no. 16, 233 no. 2 (photograph), 236 Fig. 16 (drawing).

31 André-Salvini - Salvini 2019.

32 Mora 1987, 257 XI.I.2.

33 Zehnder 2010, 164 (sub Huliyasuhani).

34 Laroche 1981, 16 no. 393a; Beyer 2001, 21 (reproduction of the drawing), 23, Pl. 4 ad no. 30.

35 Beyer 2001, 390, Fig. 95, 261, Fig. 16, Pl. B, Pl. 36 tablet 542-544). If birds of prey are here involved, they might be entered in Görke - Kozal's (2018) study.

36 Şahin - Tekoğlu 2003, 542, Fig. [4] ([b] inverted). - Definitely much rarer are the other vocables determined by M 84/ L 96, that is tar- and tar-za- of ARSUZ 1 l. 2 §7 and ARSUZ 1 l. 8 / 2 1. 7 §24b (B. Dinçol et al. 2015, 64-65, commentary 67a, 68b).

37 Meriggi - Poetto 1982, 100; Hawkins 2000, 511 at KULULU lead strip 3, side ii, register 1.

38 Hawkins 2000, 534, with commentary 542b.

39 HKM 100 vo. 20, 22 (Alp 1991, 99; Del Monte 1995, 98-99), HKM 101 vo. 5 (Del Monte 1995, 102). - For a doubtful inquiry on the sense of this formant in the PN Tarpulasdu (misprinted "Tarpa") $c f$. Zehnder (2010, 51): “'er soll in tarpala- (ein Kleidungsstück, Schärpe?) sein' (?)”. 
Here, separately, further Hieroglyphic glyptic material is worthy of discussion. It concerns a number of improper "corrections" of the original proper interpretations.

5) In $2005 / 2006$, a cylinder seal was published by Schwemer (see Fig. 4.1-2). ${ }^{40}$ His reading of the owner of the object as "Pu-mu-za/i" (pu [M 396 / L 328 var.] and zi/za [M 387.1 / L 376.2] dextroverse, $m u$ [M 108 / L 107 var. (2)] sinistroverse) was altered to "Pu-mu-wa-Z(a), le signe WA étant gravé clairement en dessous de la gueule du bovin” by Lebrun (“Un nouvel anthroponyme”), with further onomastic considerations. ${ }^{41}$ Nonetheless, the element on the right of $z i / z a$ is not the glyph wa/wi (M 394 / L 439 var.), but the known space filler L 440, ${ }^{42}$ already identified as such by Schwemer. As an additional confirmation cf., e.g., the bulla no. $4(2 \times)$ from Korucutepe ${ }^{43}$ the same applies to the final component on the Ebla impression presented by Archi: ${ }^{44}$ filler / decoration, ${ }^{45}$ not “-FRATER, (M 12a / L 276).

The beginning of the present name finds a parallel in ${ }^{\mathrm{f}} \mathrm{Pu}-\mathrm{mu}-\mathrm{ti}^{46}$ on face B of the Paris seal no. $14 .{ }^{47}$

6) A well preserved biconvex seal of the Late Bronze Age from the Syrian archaeological site of Tell Tweini ${ }^{48}$ bearing the personal name $S_{3}-k a-p i-a / i(a)$ on both faces ( $s_{3}$ [M $\left.98.1 / \mathrm{L} 104.1\right]$ and pi [M 49.2 / L 66 var.] dextroverse, $k a$ [M 281 / L 434] sinistroverse) - with the designation $\Delta$. IL 'vir' plus the title M 408a / L 438 'shepherd'49 (Fig. 5.1-2) - was provided by Bretschneider and Van Lerberghe. ${ }^{50}$

This reading of the andronym was unfoundedly criticized by Lebrun and Tavernier: "de nouvelles recherches ont donné une autre lecture", namely "Sà-us-ga-pi-ya ('don de Šauška')". ${ }^{51}$ But the rendering us ( $\mathrm{L} 421$ [/ M 390b w(a)s / us]) for what might look like a vertical stroke attached to the horn of the animal protome is entirely untenable: the glyph us has a well-defined rhomboidal shape, while the present element is simply the lower rear section of the horn. For a very similar form of $s_{3} \mathrm{cf}$. the Nişantepe seal no. 381b (here Fig. 5.3), ${ }^{52}$ where the silhouette of the appended us is clearly distinguishable and verifiable. What is more, $S_{3}-k a-p i-a / i(a)$ finds a remarkable counterpart in cun. ${ }^{\mathrm{m}}$ Sag-qa-bi; ${ }^{33}$ for the ending -pi vis-à-vis -piya note for instance ${ }^{\mathrm{m}}$ Tulpi vs. ${ }^{\mathrm{m}}$ Tulpiya.${ }^{54}$

7) In 1981, I quoted the legend on the unpublished seal of the British Museum no. 128868 (then on display), read by me through the showcase as Pa-ti-la (M 328-82-180 / L 334-90-175, all

40 Schwemer 2005-2006, 251.

41 R. Lebrun 2010, 6 §5.

42 See Laroche (1960, 227), noting already: "Distingué de wa par Güterbock, SBo II (1942) 33, et Alp, Namen (1950) 13".

43 Güterbock 1973, 138 Fig. 1, Pl. 3 Fig. 2, 142.

44 Archi 2008, 397 with Pl. 40[.1].

45 As on the outer ring of the bulla no. 133 in Herbordt 2005, Pl. 10, with 136b.

46 Reading in compliance with Mora 1987, 319 ad XIIb 1.71. Zehnder's (2010, 254) analysis ( $P u-<$ Luw. puna'ganz, alles', “mit einer graphischen Verkürzung”) seems unfeasible. In addition cf. Hawkins 2005, 269a, commentary to nos. 339-342, if the man's name represents $\mathrm{Pu}$-mu (in preference to $\mathrm{Pu}-u$ ).

47 Kennedy 1959, 153 with Pl. II (interpreted as "SCEAU?-mu-ti").

48 Located ca. $3 \mathrm{~km}$ from the coastal town of Jebleh, ca. $30 \mathrm{~km}$ south of Latakia.

49 Bossert 1960, 411-412; cf. also, among others, Gonnet 1985, 74-75.

50 Bretschneider - Van Lerberghe 2008, 33, 37 Ill. 37, and mentioned again in passing by Bretschneider et al. (2008, 37 n. 22) as well as by Al-Maqdissi et al. (2010, 33, 37 Fig. 28).

51 R. Lebrun - Tavernier 2012, 319-320, with extensive discussion on the goddess (320-326). - The interpretation of the title "VIR ${ }_{2}$ PASTOR" as 'Overseer of the domain' by Bretschneider et al. (2008, $37 \mathrm{n}$. 22), is evidently due to an oversight.

52 Herbordt 2005, Pl. 30.

53 Laroche 1981, 37 no. 1078a.

54 Laroche 1966, 188 no. 1367; 1981, 45; Zehnder 2010, 70 §165 (with further examples). 
sinistroverse). ${ }^{55}$ Subsequently, in June 1998, I could study and photograph the piece (Fig. $\left.6.1 \mathrm{a}\right){ }^{56}$ The complex on the left part of the impression of this personal name (here Fig. 6.1b), that I gave as " $\Delta .408 \mathrm{a}$ " - with M 408a = L 438 representing the "Hirtensack", hence 'shepherd"s7 -, was manipulated by Zehnder: "wobei $\Delta .408$ a als BONUS $_{2}$.FEMINA zu verstehen sein dürfte", ${ }^{58}$ evidently with $\underline{\mathrm{M}}$ 408a mistaken for $\mathrm{L} 408$, an "oval” = L 79 'femme', thus arbitrarily turning a male name into a female one!

8) Instead of the indisputable (collated!) reading f Pi-zi/za-á (M 49.2-87.1-17/ L 66 var.-376.2-19.2, all sinistroverse) of the inscription on side $b$ of the Borowski seal no. 9 (here reproduced, Fig. 6.2a[original]-2b[impression]), ${ }^{59}$ Mora's rectification "Pi-ja/i $-a$ ",${ }^{60}$ followed by Zehnder, ${ }^{61}$ has to be rejected: the "head" of the "arrow" (zi/za) is still recognizable (Fig. 6.2c, my drawing) and the short vertical stroke beside its lower section is merely a minimal scratch! My reading was, in any case, registered by Beckman as "f Pi-za-á". ${ }^{2}$

In confirmation of the validity of the writing ${ }^{\mathrm{f}} \mathrm{Pi}-z i / z a-a$ - if there is still a need to - it behooves us to call in also the masculine anthroponym Pi-zi/za-a/i(a) (a 'scribe') on a seal of the Bibliothèque National de Paris. ${ }^{63}$

A name common to both genders should not surprise: cf., one for all, ${ }^{\mathrm{f} / \mathrm{m}}$ Zizila, $^{64}$ also occurring on the Borowski seal no. 27 beside the (unpublished) piece no. 126092 of the British Museum, ${ }^{65}$ neglected by Zehnder ${ }^{66}$ but reported by Beckman. ${ }^{67}$

9) This biconvex seal was first made known by Garstang (Fig. 7.1) and subsequently by Hogarth (with decent photograph of the impression, here reproduced, Fig. 7.2). ${ }^{68}$ Mora's interpretation of face A as “Tá?-za/i-tà (o pi?)” (a 'daughter of the king', LUGAL.DUMU.MUNUS [see above, sub 2]) ${ }^{69}$ - to which Zehnder fully adheres ${ }^{70}$ - is largely unjustified. The right solution was put forward by Hawkins:71 "zi/a-pi'-zi/a-pi" (M 387.1-49-387.1-49/ L 376.2-66-376.2-66, all sinistroverse; -pi- is beyond doubt [see my drawing, Fig. 7.3]), linked to the Anatolian gyneconym Zibezibe of the Old Assyrian documents. ${ }^{72}$ In defiance of this, Mora - by means of the plain hint: "Cf. Zehnder 2010, 290, with reference to Hawkins apud Herbordt 2005, no. 285a" - persisted in the inexact rendering “Tá?/Pi?-za/i-tà”!?3

55 Poetto 1981, 34 ad no. 27 n. 62 of the Borowski collection.

56 Thanks to a permit of the Trustees of the British Museum with the friendly support of Dr. Dominique Collon.

57 Bossert 1960, 411-412.

58 Zehnder 2010, 247.

59 Poetto 1981, 19, Pl. IX.

60 Mora 1987, 155 ad VIb 1.29.

61 Zehnder 2010, 248, with profuse discussion on "Pi-i(a)?-á" as possibly identifiable with Luw. piya- 'gift'.

62 Beckman 1983, 625b ad no. 1037b.

63 Kennedy 1959, 162 no. 43, Pl. IV; Wright 1886, Pl. XVII with neat drawing, Pl. XVI no. 14 (here reproduced, Fig. 6.2d-e).

64 Laroche 1981, 51 no. 1564b; Zehnder 2010, 4, 323.

65 Poetto 1981, 34(-35) with n. 62, also recalling the Cun. oronym ${ }^{\text {HUR.SAG Zizzilla. }}$

66 Zehnder 2010, 323.

67 Beckman 1983, 626b ad no. 1564b.

68 Garstang 1908, Pl. XIV and Hogarth 1920, 90 Fig. 114.

69 Mora 1987, 140 ad VIa 3.5.

70 Zehnder 2010, 290.

71 Hawkins 2005, 285a sub no. 631 (followed by Bilgin 2018, 239 with n. 727).

72 Laroche 1966, 210 no. 1550. - At a closer look, it must be acknowledged that the name was already entirely recognizable on Hogarth's photograph.

73 Mora 2019, 636 with n. 19 ad VIa 3.5. 
10) Finally, a last clarification. In 1980, I published a seal (here Fig. 7.4a-b), belonging to a private collection, bearing the woman's name $S_{3}$-pa-pa-à (M 98.1-328b-328b-18 / L 104a-334.1-334.1-450, all dextroverse [Fig. 7.4b, impression] $)^{74}$

This result was adjusted by Mora in "Sà-pa-ha/e?-pa-à", ${ }^{75}$ and to a certain extent taken into account by Zehnder (with a possible connection with DINGIR Hepat for the presumed second member) ${ }^{76}$ However, I reaffirm that the element between the two pa's does not portray the ha pictogram (M 191 / L 215, being too small and lacking the middle vertical stroke - collated!), but represents a little ornamental globe lined up in an intermediate position, exhibited likewise, e.g., on a Berlin seal reissued by Mora herself ${ }^{77}$ (here Fig. 7.5; the sphere appears slightly out of alignment because of the space taken up by the "dagger" of tá in Tá-ti-li) or on the Nişantepe bulla no. 451 between tá and $t i$ in Tá-ti-x (here Fig. 7.6), ${ }^{78}$ not to mention the other impression from Nişantepe no. 172 under the coupled ku's of Ku-ku-la-n (supported by the two globes on each edge, here Fig. 7.7) ${ }^{79}$ and the endorsement to my reading $S_{3}$-pa-pa-à by Dinçol and Dinçol (with the interpretative option $\left.\grave{A}-S_{3}-p a-p a\right) .{ }^{80}$

\section{Acknowledgements}

Thanks are due to Zsolt Simon for some integrative remarks.

\section{Bibliography}

Al-Maqdissi, M. - Van Lerberghe, K. - Bretschneider, J. - Badawi, M. (eds.) 2010: Tell Tweini Onze campagnes de fouilles syro-belges (1999-2010). Damas.

Alp, S. 1991: Hethitische Briefe aus Maşat-Höyük. Ankara.

Alparslan, M. - Uysal, B. 2018: Ein Rollsiegel mit anatolischen Hieroglyphen aus ElbistanKarahöyük. Zeitschrift für Assyriologie und Vorderasiatische Archäologie 108, 235-239. https://doi.org/10.1515/za-2018-0018

André-Salvini, B. - Salvini, M. 2019: Note sur une bulle scellée de Ras Shamra (RS 19.160). In: MatoÏAn, V. (ed.): Archéologie, patrimoine et archives - Les fouilles anciennes à Ras Shamra et à Minet El-Beida II. Leuven - Paris - Bristol (CT), 59-62.

Archi, A. 2008: A Hittite Official at Ebla. Orientalia NS 77, 397-400, Pl. XL.

Beckman, G. 1983: A Contribution to Hittite Onomastic Studies. Journal of the American Oriental Society 103, 623-627. https://doi.org/10.2307/602045

Beyer, D. 2001: Emar IV. Les sceaux - Mission archéologique de Meskéné-Emar. Recherche au pays d'Aštata. (Orbis Biblicus et Orientalis, Series Archaeologica 20) Göttingen.

Bİlgìn, T. 2018: Officials and Administration in the Hittite World. (Studies in Ancient Near Eastern Records 21) Berlin - Boston. https://doi.org/10.1515/9781501509773

\footnotetext{
4 Poetto 1980, 3-4 no. 2, Pl. II.

Mora 1987, 324 ad XIIb 1.91.

Zehnder 2010, 265.

77 Mora 1987, 320 ad XIIb 1.75.

78 Herbordt 2005, Pl. 35.

79 See Herbordt 2005, Pl. 14.

80 Dinçol - Dinçol 1986, 239 ad no. 5A.
} 
Bossert, H. TH. 1960: Ist die B-L Schrift im wesentlichen entziffert ? Orientalia NS 29, 423-442.

Bretschneider, J. - Van Lerberghe, K. 2008: Tell Tweini, ancient Gibala, between 2600 B.C.E. and 333 B.C.E. In: Bretschneider, J. - VAn Lerberghe, K. (eds.): In Search of Gibala - An archaeological and historical study based on eight seasons of excavations at Tell Tweini (Syria) in the $A$ and $C$ fields (1999-2007). Sabadell, 11-68.

Bretschneider, J. - Van Lerberghe, K. - Vansteenhuyse, K. - Al-Maqdissi, M. 2008: The Late Bronze and Iron Age in the Jebleh Region: A View from Tell Tweini. In: Kühne, H. - Czichon, R. M. - Kreppner, F. J. (eds.): Proceedings of the $4^{\text {th }}$ International Congress of the Archaeology of the Ancient Near East, 29 March-3 April 2004, Freie Universität Berlin, 2: Social and Cultural Transformation: The Archaeology of Transitional Periods and Dark Ages. Excavation Reports. Wiesbaden, 33-46.

ÇınaroĞLu, A. - ÇElİk, D. - Güney, A. 2014: 2011 ve 2012 yılı Alaca Höyük kazıları. In: Dönmez, H. (ed.): 35. Kazı Sonuçları Toplantısı, 27-31 Mayıs 2013 3. Muğla, 6-18.

Del Monte, G. F. 1995: I testi amministrativi da Maşat Höyük/Tapika. Oriens Antiqui Miscellanea 2, 89-138.

Dínçol, A. M. - Dínçol, B. 1986: Hethitische Hieroglyphensiegel in den Museen zu Samsun, Gaziantep und Kahramanmaraş. Anadolu Araştırmaları. Jahrbuch für Kleinasiatische Forschung 10, 233-244, Pls. I-VIII

Dínçol, B. 2017: A New Tablet Fragment and a Sealed Pottery Fragment from Alacahöyük. In: Mouton, A. (ed.): Hittitology Today: Studies on Hittite and Neo-Hittite Anatolia in Honor of Emmanuel Laroche's 100 th Birthday. L'hittitologie aujourd'hui: Études sur l'Anatolie hittite et néo-hittite à l'occasion du centenaire de la naissance d'Emmanuel Laroche. İstanbul, 225-228. https://doi.org/10.4000/books.ifeagd.3558

Dínçol, B. - Dínçol, A. - Hawkins, J. D. - Peker, H. - Öztan, A. 2015: Two new inscribed Stormgod stelae from Arsuz (İskenderun): ARSUZ 1 and 2. Anatolian Studies 65, 59-77. https://doi. org/10.1017/S006615461500006X

Garstang, J. 1908: Notes on a Journey through Asia Minor. (Liverpool) Annals of Archaeology and Anthropology 1, 1-12, Pls. I-XV.

Görke, S. - Kozal, E. 2018: Birds of prey in pre-Hittite and Hittite Anatolia (c. 1970-1180 BCE): textual evidence and image representation. In: Gersmann, K.-H. - GRImm, O. (eds.): Raptor and human - falconry and bird symbolism throughout the millennia on a global scale. Kiel - Hamburg, 1667-1689.

GonnEt, H. 1985: Deux sceaux hittites inédits: Louvre AO 28064 et Erlangen S 402. Hethitica 6, 69-81.

Güterbock, H. G. 1951: Tablettes et sceaux - V. Empreintes: B. Sur de la Poterie. 1. In: KoşAY, H. Z.: Türk Tarih Kurumu Tarafından Yapılan Alaca Höyük Kazısı. 1937-1939 daki Çalışmalara ve Keşiflere Ait İlk Rapor. Les fouilles d'Alaca Höyük entreprises par la Société d'Histoire Turque. Rapport préliminaire sur les travaux en 1937-1939. Ankara, 195-196, Pl. LXXVI.

Güterвock, H. G. 1973: Hittite Hieroglyphic Seal Impressions from Korucutepe. Journal of Near Eastern Studies 32, 135-147. https://doi.org/10.1086/372227

Hawkins, J. D. 2000: Corpus of Hieroglyphic Luwian Inscriptions I. Inscriptions of the Iron Age. Berlin - New York.

Hawkins, J. D. 2005: Commentaries on the Readings / Commentary on the Sign List. In: Herbordt 2005, 248-313, 426-436. 
Hawkins, J. D. 2006: The Inscription. In: Bunnens, G.: A New Luwian Stele and the Cult of the Storm-God at Til Barsip-Masuwari. (Tell Ahmar 2) Louvain - Paris - Dudley (MA), 11-31, 146-147, Figs. 21-22.

Herbordt, S. 2005: Die Prinzen- und Beamtensiegel der hethitischen Grossreichszeit auf Tonbullen aus dem Nişantepe-Archiv in Hattusa. (Boğazköy-Ḩattuša 19) Mainz am Rhein.

Hogarth, D. G. 1920: Hittite Seals - With Particular Reference to the Ashmolean Collection. Oxford.

IsHIDA, K. (ed.) 1991: Ancient Near Eastern Seals in Japan. Tokyo.

IsHidA, K. 2017-2018: Seal Impressions on the Cuneiform Tablets from the Middle Euphrates Region in the Hirayama Collection. Bulletin of the Ancient Orient Museum 37, 13-86.

Kennedy, D. A. 1958: The Inscribed Hittite Seals in the Ashmolean Museum. Revue Hittite et Asianique 16/63, 65-84, Pls. I-V.

Kennedy, D. A. 1959: Sceaux hittites conservés à Paris. Revue Hittite et Asianique 17/65, 147-172, Pls. I-IV.

Laroche, E. 1960: Les hieroglyphes Hittites I. L’écriture. Paris.

Laroche, E. 1966: Les noms des hittites. Paris.

Laroche, E. 1981: Les noms des hittites: supplément. Hethitica 4, 3-58.

Lebrun, С . 2014: Présence et pouvoir hittites à Ougarit - Le cas des DUMU.LUGAL. Louvain-LaNeuve.

Lebrun, R. 2010: Varia scripta. In: Lebrun, R. (ed.): Syro Anatolica Scripta Minora VIII. Le Muséon 123, 1-6. https://doi.org/10.2143/MUS.123.1.2052763

Lebrun, R. - Tavernier, J. 2012: Deux objets inscrits de Tell Tweini. In: Boiy, T. - Bretschneider, J. - Goddeeris, A. - Hameeuw, H. - Jans, G. - Tavernier, J. (eds.): The Ancient Near East, a Life! Festschrift Karel Van Lerberghe. (Orientalia Lovaniensia Analecta 220) Leuven - Paris - Walpole (MA), 319-333.

Masson, E. 1975 [1977]: Quelques sceaux hittites hiéroglyphiques. Syria 52, 213-239. https://doi. org/10.3406/syria.1975.6506

Melchert, H. C. 1988: 'Thorn' and 'Minus' in Hieroglyphic Luvian Orthography. Anatolian Studies 38, 29-42. https://doi.org/10.2307/3642839

Meriggi, P. - Poetto, M. 1982: Note alle strisce di piombo di KULULU. In: Neu, E. (ed.): Investigationes philologicae et comparativae. Gedenkschrift für Heinz Kronasser. Wiesbaden, 97-115.

Mora, C. 1987: La glittica anatolica del II millennio a. C.: classificazione tipologica I. I sigilli a iscrizione geroglifica. (Studia mediterranea 6) Pavia.

Mora, C. 2019: Titles and Activities of Hittite Women: The Evidence of the Seals. In: D'AndREA, M. - Micale, M. G. - Nadali, D. - Pizzimenti, S. - Vacca, A. (eds.): Pearls of the Past. Studies on Near Eastern Art and Archaeology in Honour of Frances Pinnock. (Marru 8) Münster, 633-639.

Peker, H. 2017: Some Remarks on the Imperial Hittite Sealings from the 2017 Excavations at Karkemish. Nouvelles Assyriologiques Brèves et Utilitaires 2017, 178-179 (No. 101).

Poetтo, M. 1980: Nuovi e vecchi sigilli in luvio geroglifico. Kadmos 19, 1-8, Pls. I-III. https://doi. org/10.1515/kadmos-1980-0102 
Poetto, M. 1981: Sigilli e iscrizioni in luvio geroglifico. In: Poetto, M. - Salvatori, S.: La collezione anatolica di E. Borowski. (Studia mediterranea 3) Pavia, 11-121.

Poetto, M. 1992: Nuovi sigilli in luvio geroglifico IV. In: Otten, H. - Ertem, H. - Akurgal, E. SüEL, A. (eds.): Sedat Alp’a Armağan. Festschrift für Sedat Alp. Hittite and Other Anatolian and Near Eastern Studies in Honour of Sedat Alp. Ankara, 431-443.

Poєtтo, M. 2010: Nuovi sigilli in luvio geroglifico VII (Per il valore di á in alcune occorrenze). In: Cohen, Y. - Gilan, A. - Miller, J. L. (eds.): Pax Hethitica. Studies on the Hittites and their Neighbours in Honour of Itamar Singer. (Studien zu den Boğazköy-Texten 51) Wiesbaden, 271-277.

RÜster, Ch. - Wilhelm, G. 2012: Landschenkungsurkunden hethitischer Könige. (Studien zu den Boğazköy-Texten, Beiheft 4) Wiesbaden.

Schwemer, D. 2005-2006: Ein Siegel mit hieroglyphen-luwischer Inschrift. Archiv für Orientforschung 51, 251.

Simon, Zs. 2013: Once again on the Hieroglyphic Luwian sign *19 «á». Indogermanische Forschungen 118, 1-21. https://doi.org/10.1515/indo.2013.118.2013.1

Süel, A. - Weeden, M. 2019: A Silver Signet-Ring from Ortaköy-Sapinuwa. In: Bolatti Guzzo, N. - Taracha, P. (eds.): “And I Knew Twelve Languages". A Tribute to Massimo Poetto on the Occasion of His 70th Birthday. Warsaw, 661-668.

ŞAнİN, S. - TekoĞLu, R. 2003: A Hieroglyphic Stele from Afyon Archaeological Museum. Athenaeum 91, 540-545, Figs. 1-[4].

Uysal, B. - Çi̇fçí, A. 2018: Elbistan Karahöyük Kazısı 2016. In: Özme, A. (ed.): 39. Kazı Sonuçları Toplantısı, 22-26 Mayıs 20171. Bursa, 569-578.

VertegaAl, A. 2019 [2020]: The spelling and phonology of the dental stops in Hieroglyphic Luwian. Kadmos 58, 1-31. https://doi.org/10.1515/kadmos-2019-0001

Wright, W. ${ }^{21886:}$ The Empire of the Hittites. London.

YAmAdA, M. 2019: The 'Sons of the King' in the Emar Tablets Belonging to the Hirayama Collection. Nouvelles Assyriologiques Brèves et Utilitaires 2019, 112-114 (No. 64).

Zennder, TH. 2010: Die hethitischen Frauennamen. Katalog und Interpretation. (Dresdner Beiträge zur Hethitologie 29) Wiesbaden. 
FIG. 1.

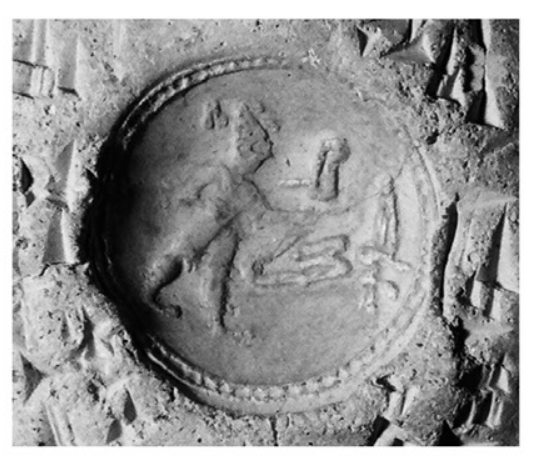

1

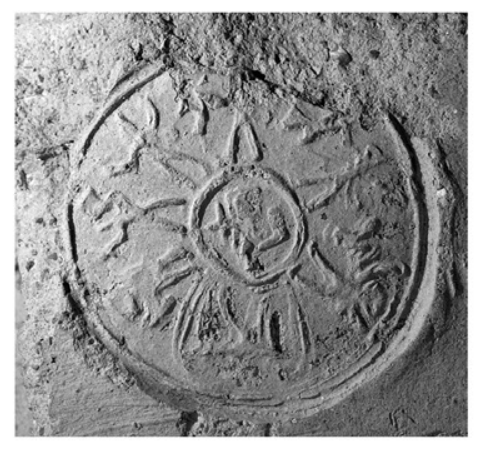

2a

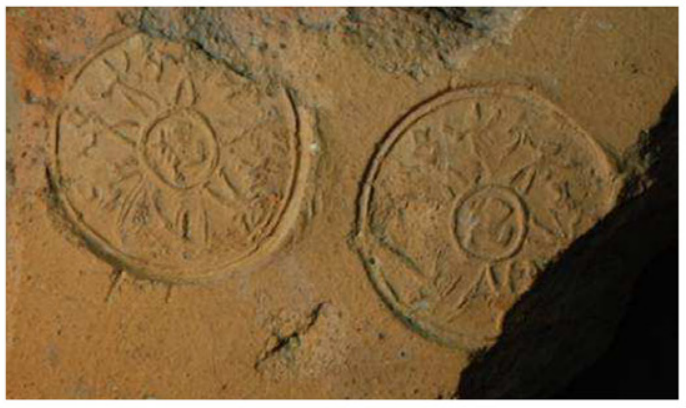

3

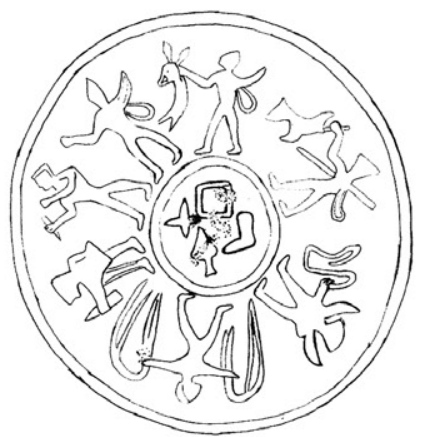

2b

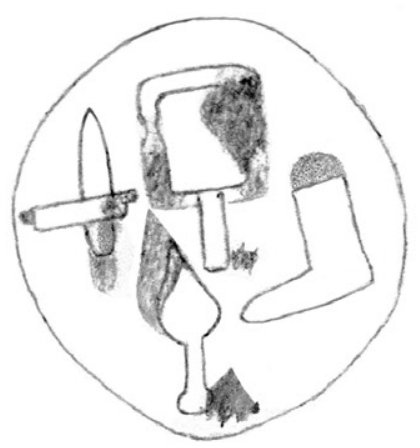

4 
FIG. 2.
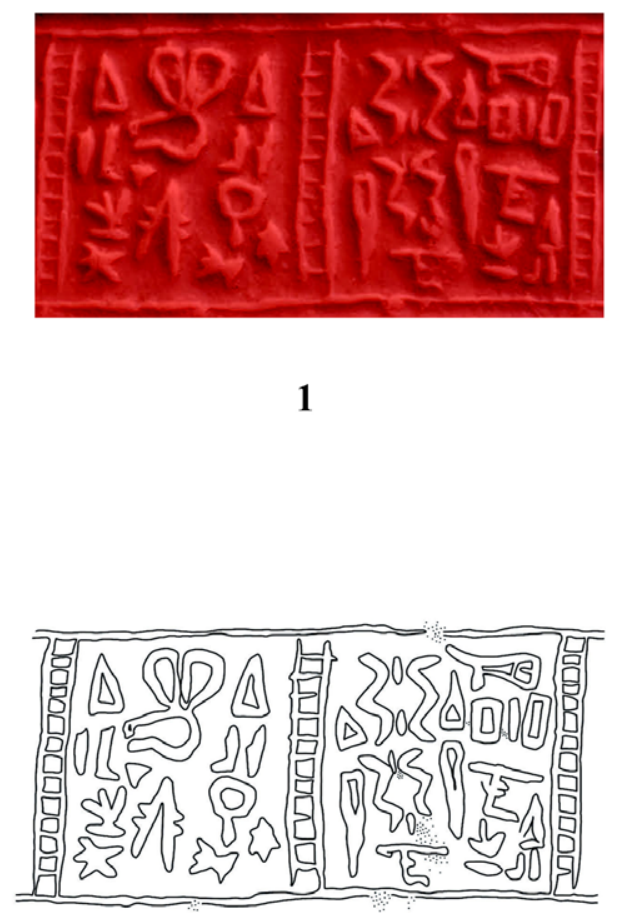

2 
FIG. 3.
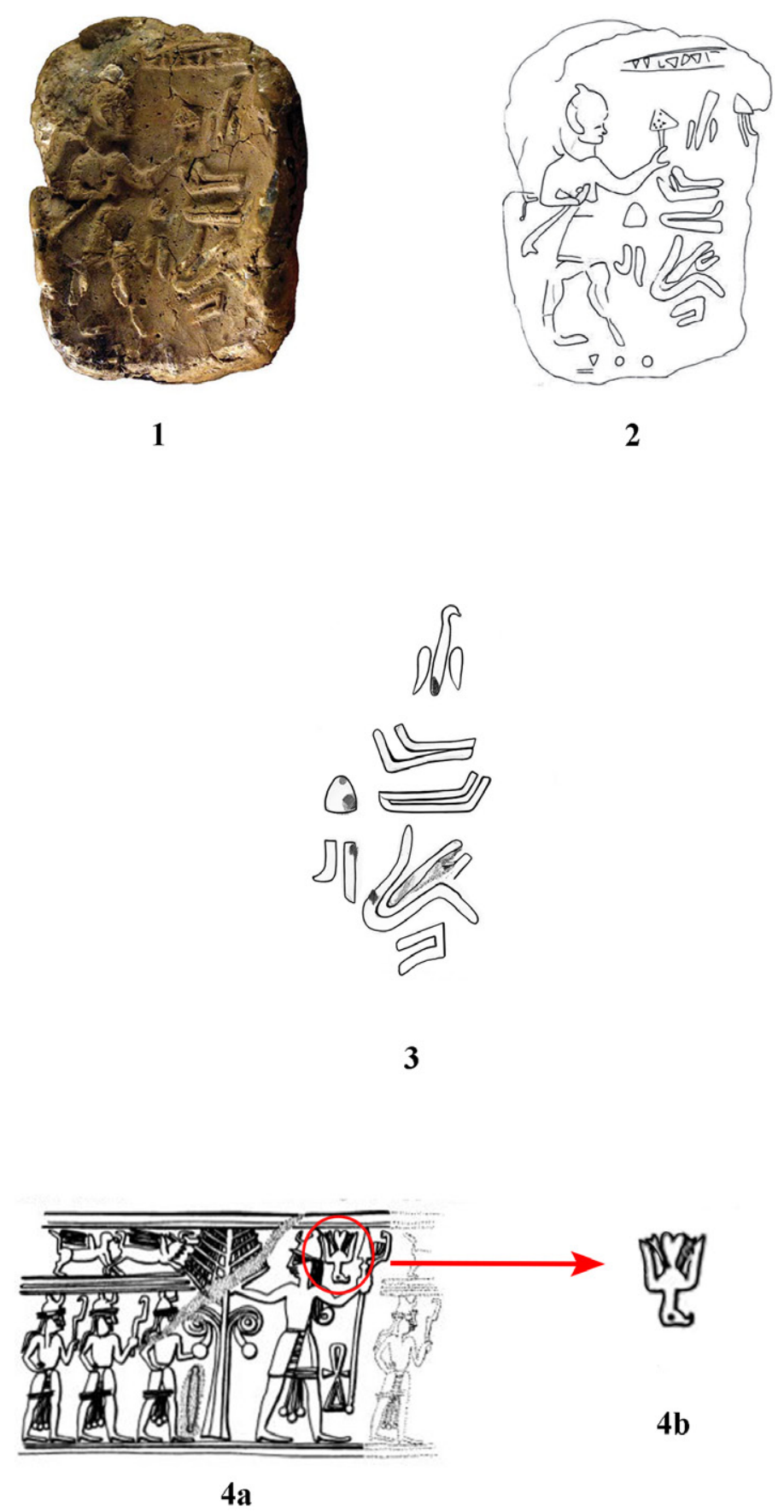
FIG. 4.
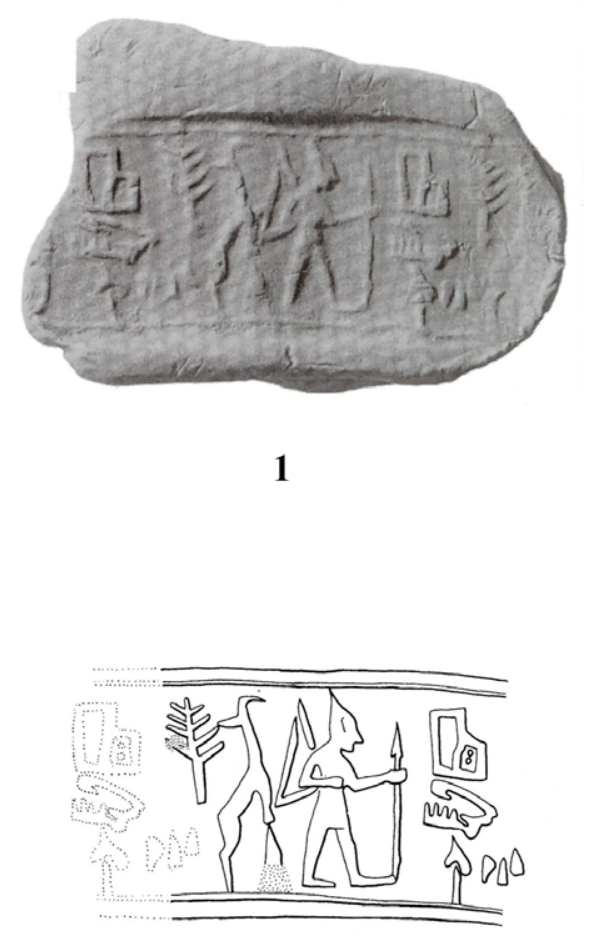
FIG. 5.
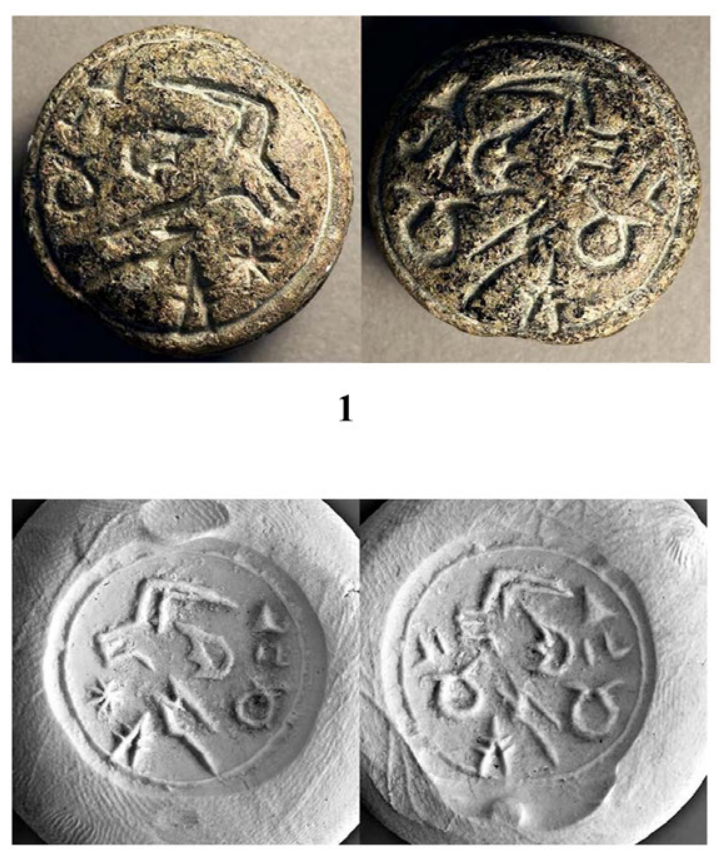

2

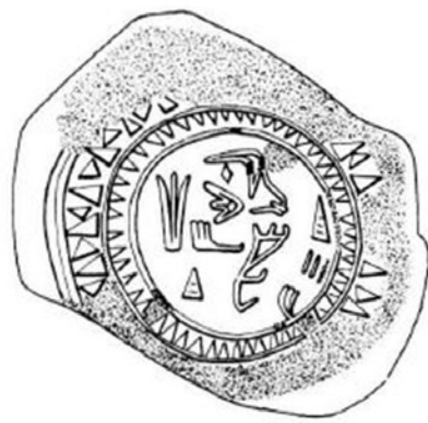

3 
FIG. 6.

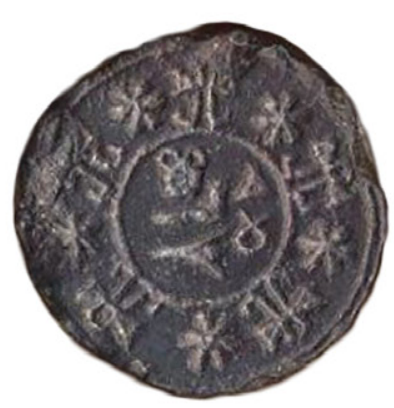

$1 \mathbf{a}$

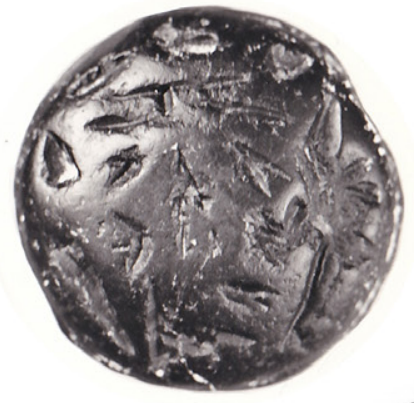

$2 \mathbf{a}$

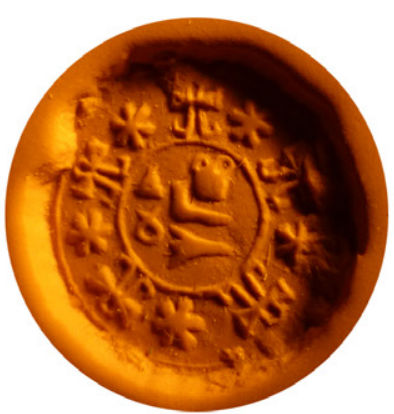

1b

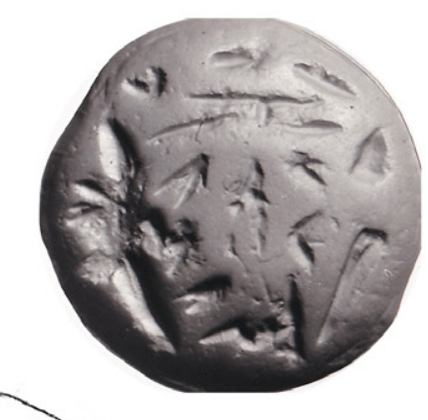

$2 b$

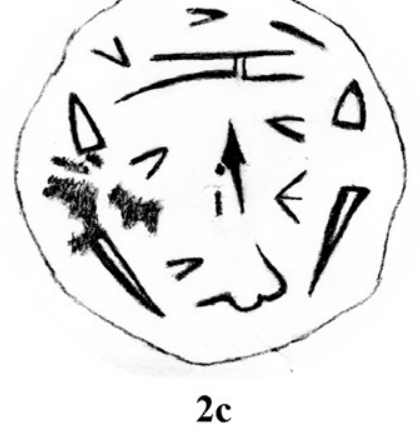

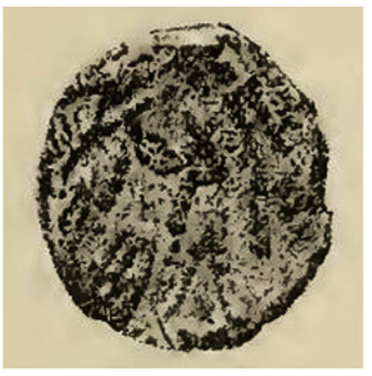

2d

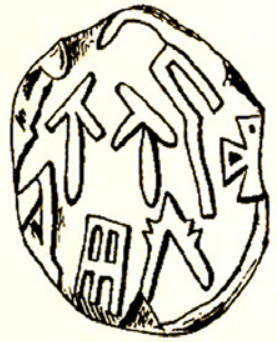

$2 \mathbf{e}$ 
FIG. 7.

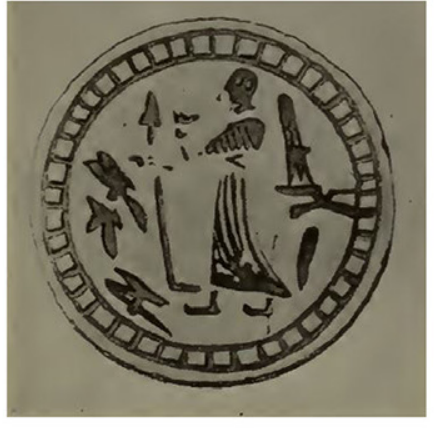

1

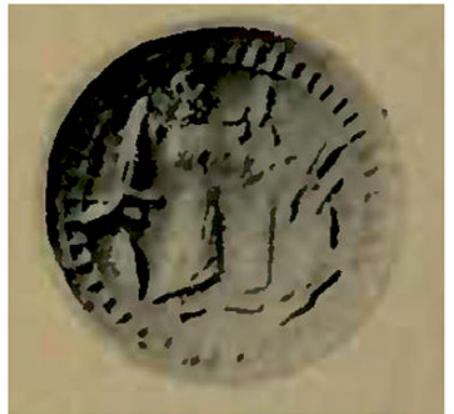

2

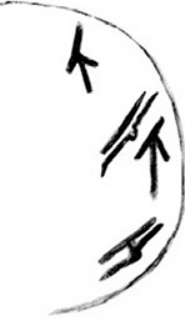

3

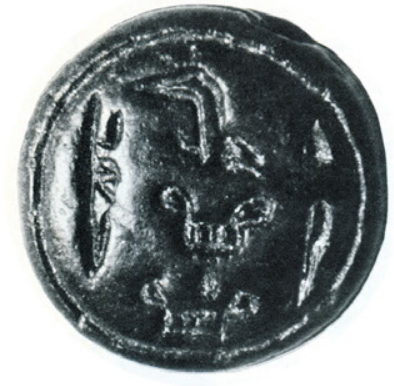

4a

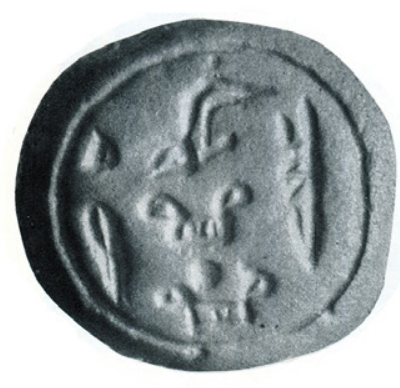

4b

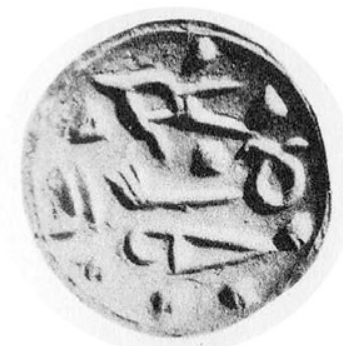

5

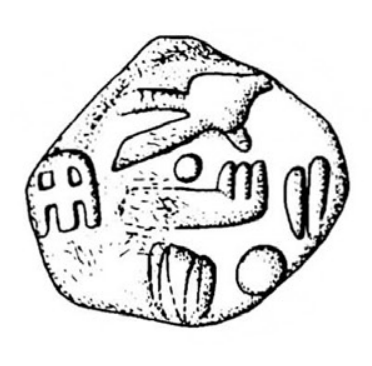

6

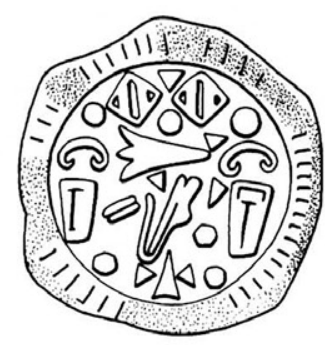

7 
奉 HAR

HUNGARIAN ASSYRIOLOGICAL REVIEW

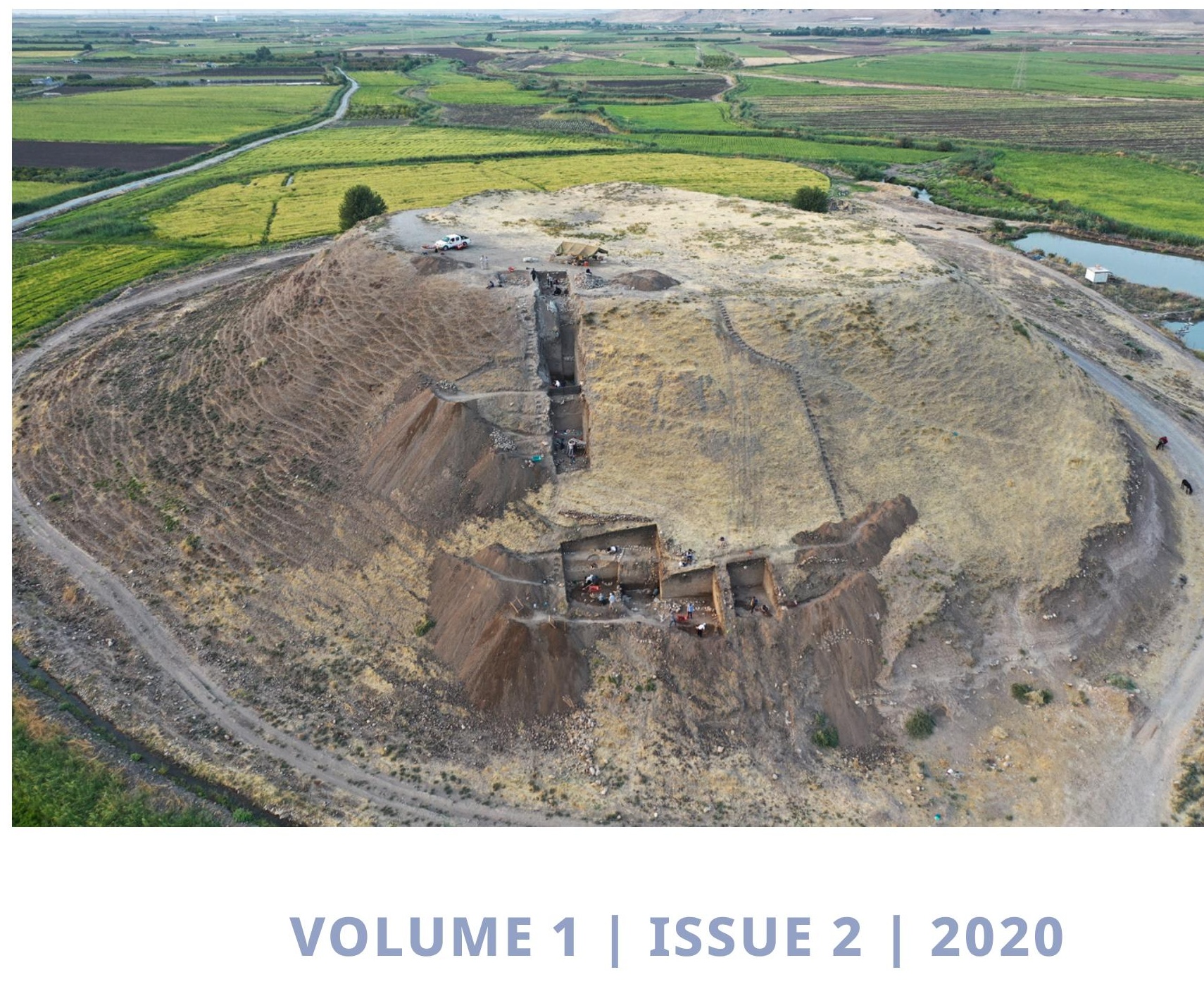





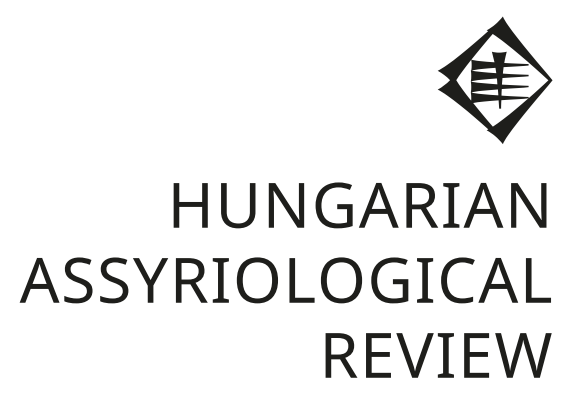


ON THE COVER:

Excavations at Grd-i Tle in 2019 -

the northern face of the tell with Trenches I and IV.

Photo: ELTE Archaeological Mission in Iraqi Kurdistan. 


\section{HUNGARIAN ASSYRIOLOGICAL REVIEW}

\section{VOLUME 1, ISSUE 2 2020}

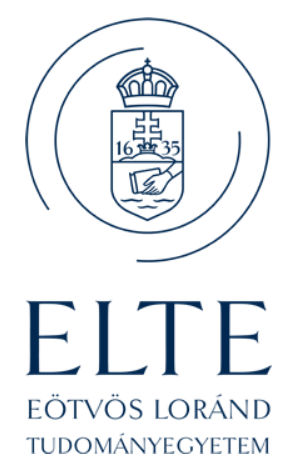

Institute of Archaeological Sciences

Institute of Ancient and Classical Studies

Eötvös Loránd University

Budapest 


\section{HUNGARIAN}

\section{HAR - Hungarian Assyriological Review}

Journal of the Institute of Archaeological Sciences and the Institute of Ancient and Classical Studies (Department of Assyriology and Hebrew Studies), Eötvös Loránd University, Budapest, Hungary.

HAR is a peer-reviewed electronic journal (HU ISSN 2732-2610) published in two issues per year. The journal covers the philology and the archaeology of the Ancient Near East, publishing research articles, brief notes, and field reports.

Papers in HAR are published under the platinum open access model, which means permanent and free access in downloadable format ( $p d f$ ) for readers and no publication fees for authors. The issues can be both downloaded for free and ordered as printed volumes at own cost.

For article submission guidelines, see https://harjournal.com/author-guidelines/

\section{Editorial board}

Editor-in-chief (szerkesztésért felelős személy):

Gábor Kalla, Eötvös Loránd University, Budapest

Associate editors:

Zsombor J. Földi, Ludwig-Maximilians-Universität, München

Zsolt Simon, Ludwig-Maximilians-Universität, München

\section{Editorial board:}

Tamás Dezső, Eötvös Loránd University, Budapest

Gábor Zólyomi, Eötvös Loránd University, Budapest

Technical editor:

Attila Király

Publisher (kiadó és kiadásért felelős személy):

Gábor Kalla, Eötvös Loránd University, Budapest

Registered office (a kiadó székhelye):

Institute of Archaeological Sciences, Múzeum krt. 4/B., 1088 Budapest, Hungary

\section{Email address:}

info@harjournal.com

\section{Design and typesetting:}

Attila Király (attila@litikum.hu)

using Noto font family by Google Inc., under the terms of the SIL Open Font License. 


\section{CONTENTS}

\section{Hungarian Assyriological Review}

\section{volume 1, issue 2,2020}

Early Babylonian tablets in the British Museum's Kuyunjik Collection 1:

A fragment of an administrative document from Ur III Girsu?

Zsombor J. Földi

The morphophonological analysis of Hittite šipantaš, šipandaš '(s)he libated'

Alwin Kloekhorst

A fresh look at recently published Anatolian hieroglyphic seals

Massimo Poetto

Floh im Ohr: Forrers Ahhijawā-Deutung, Āhhijā und ihr kilikischer Nachzügler Hijawa

Diether Schürr

\section{Hungarian Excavations at Grd-i Tle}

The geomorphological and environmental context of the Grd-i Tle archaeological site István Viczián

Hungarian Assyriological Review author guidelines 